Abstracta Iranica Abstracta Iranica

Revue bibliographique pour le domaine irano-aryen

Volume 29 | 2008

Comptes rendus des publications de 2006

\title{
Zoor khane, History and Techniques of the Ancient Martial Art of Iran. Paladin Press, Boulder, Colorado, 2006, 113 p., 123 ill., deux schémas, un tableau.
}

Philippe Rochard

\section{(2) OpenEdition}

\section{Journals}

Édition électronique

URL : http://journals.openedition.org/abstractairanica/33412

DOI : 10.4000/abstractairanica.33412

ISSN : 1961-960X

Éditeur :

CNRS (UMR 7528 Mondes iraniens et indiens), Éditions de l'IFRI

Édition imprimée

Date de publication : 15 mai 2008

ISSN : 0240-8910

Référence électronique

Philippe Rochard, "Zoor khane, History and Techniques of the Ancient Martial Art of Iran. Paladin Press, Boulder, Colorado, 2006, 113 p., 123 ill., deux schémas, un tableau. », Abstracta Iranica [En ligne],

Volume 29 | 2008, document 420, mis en ligne le 15 septembre 2008, consulté le 26 septembre 2020.

URL : http://journals.openedition.org/abstractairanica/33412 ; DOI : https://doi.org/10.4000/

abstractairanica.33412

Ce document a été généré automatiquement le 26 septembre 2020.

Tous droits réservés 


\title{
Zoor khane, History and Techniques of the Ancient Martial Art of Iran. Paladin Press, Boulder, Colorado, 2006, 113 p., 123 ill., deux schémas, un
} tableau.

\author{
Philippe Rochard
}

1 Que dire d'un auteur qui prétend offrir au lecteur un ouvrage consacré à l'histoire et aux techniques corporelles du zūrHāne et qui affiche sans honte une bibliographie constituée de trois références ? Dès que celui-ci s'écarte de la simple description des exercices, chaque page apporte son lot d'erreurs et d'interprétations comiques qu'il forge pour tenter d'appuyer un postulat intenable : l'origine martiale des exercices enseignés dans les zūrtuāne. Nous passons sur le traitement historique de l'institution qui provoque quelques bons rires nerveux ou encore sur le chapitre consacré aux relations entretenues par les zūrHūne avec les femmes... Ce dernier passage vaut le détour (p. 28) : les femmes ne sont pas admises dans les zurkhâneh parce qu'elles risqueraient de déconcentrer les athlètes au moment où ceux-ci manipulent des objets de musculation particulièrement lourds et dangereux... Mesdames, vous voici prévenues, si vous ne voulez pas qu'un pauvre novice se fracasse le crâne avec son mïl en vous dévisageant d'un air hagard, évitez les zūrHāne. 
INDEX

Thèmes : 16.1. Iran

\section{AUTEURS}

PHILIPPE ROCHARD

Université Marc Bloch - Strasbourg 